\title{
Highly Active Palladium Catalysts Supported by Bulky Proazaphosphatrane Ligands for Stille Cross-Coupling: Coupling of Aryl and Vinyl Chlorides, Room Temperature Coupling of Aryl Bromides, Coupling of Aryl Triflates, and Synthesis of Sterically Hindered Biaryls
}

\author{
Weiping Su, Sameer Urgaonkar, Patrick A. McLaughlin, and John G. Verkade* \\ Department of Chemistry, Gilman Hall, Iowa State University, Ames, Iowa 50011 \\ jverkade@iastate.edu
}

Supporting information

\section{TABLE OF CONTENTS}

\section{Contents}

1) General considerations, experimental procedures

2) References for known compounds
Page number

S2-S26

S26-S28

\section{General Considerations}

2-Mesityltributylstannane, ${ }^{1}$ o-tolyltributylstannane, ${ }^{1}$ 4-(tributylstannyl)nitrobenzene, ${ }^{2}$ 4- 
tert-butylphenyltriflate, ${ }^{3} \quad$ bis(2-aminoethyl)(2-benzylaminoethyl)amine, ${ }^{4} \quad$ bis[2benzylamino)ethyl](2-aminoethyl)amine, ${ }^{4}$ and $\operatorname{tris}[2$-(benzylamino)ethyl $] a_{m i n e}{ }^{5}$ were prepared following literature procedures. All other reagents were commercially available and were used as re ceived unless otherwise noted. Cesium fluoride (Aldrich) was ground to fine powder and then dried under vacuum at $100{ }^{\circ} \mathrm{C}$ for $12 \mathrm{~h}$ prior to use. THF, $1,4-$ dioxane, and pentane were distilled from $\mathrm{Na}$ /benzophenone under argon and degassed prior to use. Acetonitrile was distilled from $\mathrm{CaH}_{2}$ under argon. Anhydrous DMF was purchased from Aldrich. For convenience, stock solutions of 1 and $\mathbf{2}$ in 1,4-dioxane (2 $\mathrm{mM}$ ) were prepared and stored under argon. All reactions were performed under an atmosphere of argon in oven-dried glassware. ${ }^{1} \mathrm{H}$ and ${ }^{13} \mathrm{C}$ NMR spectra were recorded at 300 and $75 \mathrm{MHz}$, respectively, unless otherwise noted. The yields reported are isolated yields and are the average of two runs.

Synthesis of Ligand 2. To a solution of $20.9 \mathrm{~g}(88.56 \mathrm{mmol})$ of bis(2-aminoethyl)(2benzylaminoethyl)amine in $30 \mathrm{~mL}$ of methanol was added $17.2 \mathrm{~g}(238.89 \mathrm{mmol})$ of isobutyraldehyde through a dropping funnel over 20 minutes. The mixture was allowed to stir for $3 \mathrm{~h}$ after which $200 \mathrm{~mL}$ of methanol was added. The resulting solution was allowed to cool to $0^{\circ} \mathrm{C}$ in an ice bath and then $11.1 \mathrm{~g}$ of sodium borohydride was added portion-wise over $1 \mathrm{~h}$. The reaction mixture was allowed to stir overnight. Removal of solvent in vacuo afforded a white residue, which was dissolved by the addition of $200 \mathrm{~mL}$ of water and extracted with $\mathrm{CH}_{2} \mathrm{Cl}_{2}(3 \times 150 \mathrm{~mL})$. The organic extracts were combined, washed with brine $(50 \mathrm{~mL})$, and dried over $\mathrm{Na}_{2} \mathrm{SO}_{4}$. The solvent was removed in vacuo and the resulting liquid was distilled under vacuum $\left(135-142{ }^{\circ} \mathrm{C} / 210 \mathrm{mTorr}\right)$ to afford $29.4 \mathrm{~g}$ of bis[(2-iso-butylamino)ethyl][(2-benzylamino)ethyl]amine. 
A solution of $29.4 \mathrm{~g} \quad(84.5 \mathrm{mmol})$ of bis[(2-iso-butylamino)ethyl][(2benzylamino)ethyl]amine in $50 \mathrm{~mL}$ of $\mathrm{CH}_{3} \mathrm{CN}$ was added to $84.4 \mathrm{mmol}$ of $\mathrm{ClP}\left(\mathrm{NMe}_{2}\right)_{2}$ uner argon, prepared in situ in $100 \mathrm{~mL}$ of $\mathrm{CH}_{3} \mathrm{CN}$ by the slow addition of $2.52 \mathrm{~mL}$ (28.1 mmol) of $\mathrm{PCl}_{3}$ to $10.3 \mathrm{~mL}(56.3 \mathrm{mmol})$ of $\mathrm{P}\left(\mathrm{NMe}_{2}\right)_{3}$ at $0{ }^{\circ} \mathrm{C}$ in an ice bath. A white solid was formed in the beginning of reaction, and dissolved as the reaction progressed. The reaction mixture was stirred for $0.5 \mathrm{~h}$ at $0{ }^{\circ} \mathrm{C}$, then overnight at room temperature. Removal of solvent under vacuum resulted in a viscous oil which was dissolved in $30 \mathrm{~mL}$ of THF. Addition of $200 \mathrm{~mL}$ of hexanes to the resulting solution afforded a white precipitate from which the solvent was decanted. The obtained precipitate was washed with ether $(3 \quad \mathrm{x} \quad 80 \mathrm{~mL})$ and dried under vacuum to give $29.8 \mathrm{~g}$ of $\left[\mathrm{HP}\left(\mathrm{Me}_{2} \mathrm{CHNCH}_{2} \mathrm{CH}_{2}\right)_{2}\left(\mathrm{PhCH}_{2} \mathrm{NCH}_{2} \mathrm{CH}_{2}\right) \mathrm{N}\right] \mathrm{Cl}$ as a white solid.

To a mixture of $29.8 \mathrm{~g}(72.2 \mathrm{mmol})$ of $\left[\mathrm{HP}\left(\mathrm{Me}_{2} \mathrm{CHNCH}_{2} \mathrm{CH}_{2}\right)_{2}\left(\mathrm{PhCH}_{2} \mathrm{NCH}_{2} \mathrm{CH}_{2}\right) \mathrm{N}\right] \mathrm{Cl}$ and $16.2 \mathrm{~g}(144.6 \mathrm{mmol})$ of $t$-BuOK in a $500 \mathrm{~mL}$ Schlenk flask was added $150 \mathrm{~mL}$ of dry THF under argon. The reaction mixture was stirred overnight and then THF was distilled off under vacuum. Pentane $(2 \times 150 \mathrm{~mL})$ was added to the remaining residue under argon and the mixture was stirred for $1 \mathrm{~h}$ and then allowed to settle for $3 \mathrm{~h}$. The clear upper layer was transferred through cannula into a $500 \mathrm{~mL}$ Schlenk flask. The combined organic extracts were concentrated in vacuo to give a light yellow oil which was further purified by vacuum distillation $\left(150^{\circ} \mathrm{C} / 140 \mathrm{mTorr}\right)$ to afford a $16.6 \mathrm{~g}$ of 2 as a pale yellow oil (overall yield: $58 \%$ ). ${ }^{1} \mathrm{H}$ NMR $\left(\mathrm{C}_{6} \mathrm{D}_{6}\right): \delta 7.35(\mathrm{~d}, J=7.4 \mathrm{~Hz}, 2 \mathrm{H}), 7.21-7.16$ (m, 2H), 7.09-7.04 (m, 2H), $4.08(\mathrm{~d}, J=8.9 \mathrm{~Hz}, 2 \mathrm{H}), 2.78-2.63$ (overlapping region, $16 \mathrm{H}), 1.81$ (septet, $J=6.7 \mathrm{~Hz}, 2 \mathrm{H}), 0.93(\mathrm{~d}, J=6.7 \mathrm{~Hz}, 6 \mathrm{H}), 0.91(\mathrm{~d}, J=6.5 \mathrm{~Hz}, 6 \mathrm{H}) .{ }^{13} \mathrm{C}$ $\operatorname{NMR}\left(\mathrm{C}_{6} \mathrm{D}_{6}\right): \delta 141.9(\mathrm{~d}, J=6.2 \mathrm{~Hz}), 128.4,128.3,126.8,58.3(\mathrm{~d}, J=37.0 \mathrm{~Hz}), 53.5(\mathrm{~d}$, 
$J=42.2 \mathrm{~Hz}), 51.4(\mathrm{~d}, J=3.0 \mathrm{~Hz}), 51.2(\mathrm{~d}, J=3.0 \mathrm{~Hz}), 46.6(\mathrm{~d}, J=6.7 \mathrm{~Hz}), 45.3(\mathrm{~d}, J=$ $6.7 \mathrm{~Hz}), 28.6(\mathrm{~d}, J=5.1 \mathrm{~Hz}), 20.7(\mathrm{~d}, J=1.6 \mathrm{~Hz}), 20.69(\mathrm{~d}, J=1.6 \mathrm{~Hz}) .{ }^{31} \mathrm{P}$ NMR $\left(\mathrm{C}_{6} \mathrm{D}_{6}\right)$ : $\delta$ 130.0. HRMS $m / z$ Calcd for $\mathrm{C}_{21} \mathrm{H}_{37} \mathrm{~N}_{4} \mathrm{P}: 376.27559$. Found: 376.27508. Anal. Calcd. for $\mathrm{C}_{21} \mathrm{H}_{37} \mathrm{~N}_{4} \mathrm{P}: \mathrm{C}, 66.97 ; \mathrm{H}, 9.91 ; \mathrm{N}, 14.89$. Found: $\mathrm{C}, 67.13 ; \mathrm{H}, 9.81 ; \mathrm{N}, 14.83$.

Synthesis of Ligand 3. To a solution of $15.58 \mathrm{~g}(47.6 \mathrm{mmol})$ of bis[(2benzylamino)ethyl] (2-aminoethyl)amine in $30 \mathrm{~mL}$ of methanol was added $4.43 \mathrm{~g}$ (61.5 mmol) of isobutyraldehyde through a dropping funnel over 20 minutes. The mixtrure was allowed to stir for $3 \mathrm{~h}$ after which $200 \mathrm{~mL}$ of methanol was added. The resulting solution was allowed to cool to $0{ }^{\circ} \mathrm{C}$ in an ice-bath and then $3.8 \mathrm{~g}$ of sodium borohydride was added portion-wise over $0.5 \mathrm{~h}$. The reaction mixture was allowed to stir overnight. Removal of solvent under reduced pressure afforded a white residue, which was dissolved by the addition of $200 \mathrm{~mL}$ of water. The reaction mixture was extracted with methylene chloride $(3 \times 150 \mathrm{~mL})$. The organic extracts were combined and washed with brine $(50 \mathrm{~mL})$, dried over anhydrous sodium sulfate and concentrated under reduced pressure to give light yellow oil. The crude material was purified by chromatography on silica gel $\left(\mathrm{CH}_{2} \mathrm{Cl}_{2} / \mathrm{MeOH}\right.$, v:v $\left.=6: 4\right)$ to afford $16 \mathrm{~g}$ of bis [(2-benzylamino)ethyl] [(2-isobutylamino)ethyl]amine.

A procedure analogous to that for synthesis of 2 from bis[(2-iso-butylamino)ethyl] -[(2benzylamino)ethyl]amine was followed for the preparation of $\mathbf{3}$ from bis[(2benzylamino)ethyl $] \quad$ [(2-iso-butylamino)ethyl $]$ amine. The reaction of bis[(2benzylamino)ethyl][(2-iso-butylamino)ethyl]amine (16 g, $41.88 \mathrm{mmol})$ with $1.25 \mathrm{~mL}$ (13.9 mmol) of $\mathrm{PCl}_{3}$ and $5.1 \mathrm{~mL}(27.84 \mathrm{mmol})$ of $\mathrm{P}\left(\mathrm{NMe}_{2}\right)_{3}$ afforded $15.2 \mathrm{~g} \mathrm{(34.1}$ mmol) of $\left[\mathrm{HP}\left(\mathrm{Me}_{2} \mathrm{CHNCH}_{2} \mathrm{CH}_{2}\right)\left(\mathrm{PhCH}_{2} \mathrm{NCH}_{2} \mathrm{CH}_{2}\right)_{2} \mathrm{~N}\right] \mathrm{Cl}$, which was deprotonated with 
$7.64 \mathrm{~g}(68.2 \mathrm{mmol})$ of $t$-BuOK to give 3 . The crude product was recrystallized from pentane to afford $13.0 \mathrm{~g}$ of $\mathbf{3}$ as a white solid (overall yield: $66 \%$ ). ${ }^{1} \mathrm{H}$ NMR $\left(\mathrm{C}_{6} \mathrm{D}_{6}\right): \delta$ $7.36(\mathrm{~d}, J=7.2 \mathrm{~Hz}, 4 \mathrm{H}), 7.21-7.16(\mathrm{~m}, 4 \mathrm{H}), 7.07-7.05(\mathrm{~m}, 2 \mathrm{H}), 4.11(\mathrm{~d}, J=9.1 \mathrm{~Hz}, 4 \mathrm{H})$, 2.81-2.75 (m, 2H), 2.69-2.58 (m, 12H), 1.80 (septet, $J=6.7 \mathrm{~Hz}, 1 \mathrm{H}), 0.93(\mathrm{~d}, J=6.7$, 6H). ${ }^{13} \mathrm{C}$ NMR $\left(\mathrm{C}_{6} \mathrm{D}_{6}\right): \delta 141.7(\mathrm{~d}, J=6.2 \mathrm{~Hz}), 128.4(\mathrm{~s}), 128.3(\mathrm{~d}, J=2.1 \mathrm{~Hz}), 126.9(\mathrm{~s})$, $57.9(\mathrm{~d}, J=36.6 \mathrm{~Hz}), 53.4(\mathrm{~d}, J=41.4 \mathrm{~Hz}), 51.4(\mathrm{~d}, J=11.8 \mathrm{~Hz}), 51.1(\mathrm{~d}, J=2.7 \mathrm{~Hz})$, $46.5(\mathrm{~d}, J=6.7 \mathrm{~Hz}), 45.3(\mathrm{~d}, J=6.7 \mathrm{~Hz}), 28.6(\mathrm{~d}, J=5.1 \mathrm{~Hz}), 20.7(\mathrm{~d}, J=1.6 \mathrm{~Hz}) .{ }^{31} \mathrm{P}$ NMR $\left(\mathrm{C}_{6} \mathrm{D}_{6}\right): \delta$ 128.9. HRMS $m / z$ Calcd for $\mathrm{C}_{24} \mathrm{H}_{35} \mathrm{~N}_{4} \mathrm{P}: 410.25299$. Found: 410.26040 . Anal. Calcd. for $\mathrm{C}_{24} \mathrm{H}_{35} \mathrm{~N}_{4} \mathrm{P}: \mathrm{C}, 70.20 ; \mathrm{H}, 8.60 ; \mathrm{N}, 13.66$. Found: $\mathrm{C}, 70.25 ; \mathrm{H}, 8.44 ; \mathrm{N}$, 13.56.

Synthesis of Ligand 4. A procedure analogous to that for synthesis of 2 from bis(2-isobutylaminoethyl)(2-benzylaminoethyl)amine was followed for the preparation of $\mathbf{4}$ from tris[2-(benzylamino)ethyl]amine. The reaction of $32 \mathrm{~g}(76.94 \mathrm{mmol})$ of tris[(2benzylamino)ethyl]amine with $2.3 \mathrm{~mL}(25.6 \mathrm{mmol})$ of $\mathrm{PCl}_{3}$ and $9.4 \mathrm{~mL}(51.3 \mathrm{mmol})$ of $\mathrm{P}\left(\mathrm{NMe}_{2}\right)_{3}$ afforded $30 \mathrm{~g}(62.4 \mathrm{mmol})$ of $\left[\mathrm{HP}\left(\mathrm{PhCH}_{2} \mathrm{NCH}_{2} \mathrm{CH}_{2}\right)_{3} \mathrm{~N}\right] \mathrm{Cl}$, which was deprotonated with $14.0 \mathrm{~g}(125 \mathrm{mmol})$ of $t$-BuOK to give 4 . The crude product was recrystallyzed from pentane to afford $24.9 \mathrm{~g}(56.2 \mathrm{mmol})$ of 4 as a off-white solid (overall yield: $73 \%) .{ }^{1} \mathrm{H}$ NMR $\left(\mathrm{C}_{6} \mathrm{D}_{6}\right): \delta 7.36(\mathrm{~d}, J=5.5 \mathrm{~Hz}, 6 \mathrm{H}), 7.35-7.17(\mathrm{~m}, 6 \mathrm{H}), 7.11-7.09$ (m, 3H), $4.13(\mathrm{~d}, J=6.9 \mathrm{~Hz}, 6 \mathrm{H}), 2.66-2.63(\mathrm{~m}, 6 \mathrm{H}), 2.56-2.54(\mathrm{~m}, 6 \mathrm{H}) .{ }^{13} \mathrm{C}$ NMR $\left(\mathrm{C}_{6} \mathrm{D}_{6}\right): \delta 141.6(\mathrm{~d}, J=5.9 \mathrm{~Hz}), 128.5(\mathrm{~s}), 128.3(\mathrm{~d}, J=2.1 \mathrm{~Hz}), 127.0(\mathrm{~s}), 53.1(\mathrm{~d}, J=$ $41.1 \mathrm{~Hz}), 51.0(\mathrm{~d}, J=2.7 \mathrm{~Hz}), 45.4(\mathrm{~d}, J=6.7 \mathrm{~Hz}) .{ }^{31} \mathrm{P}$ NMR $\left(\mathrm{C}_{6} \mathrm{D}_{6}\right): \delta 127.9$. HRMS $m / z$ Calcd for $\mathrm{C}_{27} \mathrm{H}_{33} \mathrm{~N}_{4} \mathrm{P}: 444.24429$. Found: 444.24510 .

General Procedure for Stille Cross-Coupling reaction Using Ligand 1 (Procedure A). 
In a glove box, the Schlenk tube equipped with a stir bar was charged with $\operatorname{Pd}_{2}(\mathrm{dba})_{3}$ (11.2 $\mathrm{mg}, 0.012 \mathrm{mmol}, 1.5 \mathrm{~mol} \%)$ CsF $(272 \mathrm{mg}, 1.8 \mathrm{mmol})$. The tube was fitted with a rubber septum and removed out of the glove box. One $\mathrm{mL}$ of 1,4-dioxane, stock solution of ligand 1 in dioxane (16.8 mg, $0.049 \mathrm{mmol}, 6 \mathrm{~mol} \%$ ), aryl chloride (1.0 equiv, aryl chloride if solid was added inside the glove box), and organotin reagent (1.1 equiv) were added successively using syringes. The tube was sealed with a Teflon screwcap. The reaction mixture was stirred for 30 minutes at room temperature then heated with stirring at the indicated temperature for the indicated time. The reaction mixture was cooled to room temperature, diluted with ether or acetone, filtered, and concentrated in vacuo. The crude product was purified by column chromatography on silica gel.

\section{General Procedure for Stille Cross-Coupling Reaction Using Ligand 4 (Procedure}

B). In a glove box, the Schlenk tube equipped with a stir bar was charged with $\operatorname{Pd}_{2}(\mathrm{dba})_{3}$ (11.2 mg, $0.012 \mathrm{mmol}, 1.5 \mathrm{~mol} \%$ ), CsF (272 mg, $1.8 \mathrm{mmol}$ ), and ligand 4 (11 mg, 0.025 mmol, $3.5 \mathrm{~mol} \%)$. The tube was fitted with a rubber septum and removed out of the glove box. One $\mathrm{mL}$ of 1,4-dioxane, aryl chloride (1.0 equiv, aryl chloride if solid was added inside the glove box), and organotin reagent (1.1 equiv) were added successively using syringes. The tube was sealed with a Teflon screwcap. The reaction mixture was stirred for 30 minutes at room temperature then heated with stirring at the indicated temperature for the indicated time. The reaction mixture was cooled to room temperature, diluted with ether or acetone, filtered, and concentrated in vacuo. The crude product was purified by column chromatography on silica gel.

General Procedure For the Synthesis of Sterically Hindered Biaryls Using Ligand 3 (Procedure C). In a glove box, the Schlenk tube equipped with a stir bar was charged 
with $\mathrm{Pd}_{2}(\mathrm{dba})_{3}(7 \mathrm{mg}, 0.0075 \mathrm{mmol}, 1.5 \mathrm{~mol} \%), \mathrm{CsF}(168 \mathrm{mg}, 1.1 \mathrm{mmol})$, and ligand 3 (7.2 $\mathrm{mg}, 0.0175 \mathrm{mmol}, 3.5 \mathrm{~mol} \%$ ). The tube was fitted with a rubber septum and removed out of the glove box. Aryl halide (1.0 equiv), 1,4-dioxane ( $1 \mathrm{~mL})$, and organotin reagent (1.1 equiv) were added successively using syringes. The tube was sealed with a Teflon screwcap. The reaction mixture was stirred for 30 minutes at room temperature then heated with stirring at the indicated temperature for the indicated time. The reaction mixture was cooled to room temperature, diluted with ether or acetone, filtered, and concentrated in vacuo. The crude product was purified by column chromatography on silica gel.

General procedure For Room-Temperature Stille reactions of Aryl Bromides Using Ligand 4 (Procedure D). In a glove box, the Schlenk tube equipped with a stir bar was charged with $\mathrm{Pd}_{2}(\mathrm{dba})_{3}(11.2 \mathrm{mg}, 0.012 \mathrm{mmol}, 1.5 \mathrm{~mol} \%), \mathrm{CsF}(272 \mathrm{mg}, 1.8 \mathrm{mmol})$, and ligand 4 (11 mg, $0.025 \mathrm{mmol}, 3.0 \mathrm{~mol} \%)$. The tube was fitted with a rubber septum and removed out of the glove box. One $\mathrm{mL}$ of THF, aryl bromide (1.0 equiv) and organotin reagent (1.1 equiv) were added successively using syringes. The tube was sealed with a Teflon screwcap. The reaction mixture was stirred at room temperature for the indicated time, and then diluted with ether or acetone, filtered and concentrated in vacuo. The crude product was purified by column chromatography on silica gel.

Methyl 4-vinylbenzoate ${ }^{6}$ (Table 1, entry 1). Procedure A was followed using methyl 4chlorobenzoate $(140 \mathrm{mg}, 0.816 \mathrm{mmol})$ and vinyltributyltin $(0.27 \mathrm{~mL}, 0.898 \mathrm{mmol})$. The reaction mixture was purified by column chromatography on silica gel (1\% ethyl acetate/hexanes) to afford $123 \mathrm{mg}(93 \%)$ of the desired product as a white solid. ${ }^{1} \mathrm{H}$ NMR $\left(300 \mathrm{MHz}, \mathrm{CDCl}_{3}\right): \delta 7.99(\mathrm{~d}, J=8.4 \mathrm{~Hz}, 2 \mathrm{H}), 7.45(\mathrm{~d}, J=8.4 \mathrm{~Hz}, 2 \mathrm{H}), 6.74(\mathrm{dd}, J$ 
$=17.5,11.0 \mathrm{~Hz}, 1 \mathrm{H}), 5.86(\mathrm{~d}, J=17.5 \mathrm{~Hz}, 1 \mathrm{H}), 5.38(\mathrm{~d}, J=11.0 \mathrm{~Hz}, 1 \mathrm{H}), 3.90(\mathrm{~s}, 3 \mathrm{H})$.

${ }^{13} \mathrm{C}$ NMR (75.5 MHz, $\left.\mathrm{CDCl}_{3}\right): \delta 167.1,142.1,136.2,130.1,129.5,126.3,116.7,52.3$.

4-Nitrobiphenyl ${ }^{7}$ (Table 1, entry 2). Procedure A was followed using 1-chloro-4nitrobenzene $(130 \mathrm{mg}, 0.816 \mathrm{mmol})$ and phenyltributyltin $(0.30 \mathrm{~mL}, 0.898 \mathrm{mmol})$. The reaction mixture was purified by column chromatography on silica gel ( $2 \%$ ethyl acetate/hexanes) to afford $140 \mathrm{mg}(86 \%)$ of the desired product as a light yellow solid. The ${ }^{1} \mathrm{H}$ and ${ }^{13} \mathrm{C}$ NMR spectra were in accordance with those described in the literature.

4-Phenylbenzaldehyde (Table 1, entry 3). Procedure A was followed using 4chlorobenzaldehyde (118 $\mathrm{mg}, 0.816 \mathrm{mmol})$ and phenyltributyltin $(0.30 \mathrm{~mL}, 0.898 \mathrm{mmol})$. The reaction mixture was purified by column chromatography on silica gel (3\% ethyl acetate/hexanes) to afford $133 \mathrm{mg}(89 \%)$ of the desired product as a white solid. The product was identical with an authentic material (Aldrich) by ${ }^{1} \mathrm{H}$ and ${ }^{13} \mathrm{C}$ NMR spectra.

4-Phenylbenzophenone (Table 1, entry 4) Procedure A was followed using 4chlorobenzophenone $(179 \mathrm{mg}, 0.816 \mathrm{mmol})$ and phenyltributyltin $(0.30 \mathrm{~mL}, 0.898$ mmol). The reaction mixture was purified by column chromatography on silica gel ( $3 \%$ ethyl acetate/hexanes) to afford $196 \mathrm{mg}(93 \%)$ of the desired product as a white solid. The product was identical with an authentic material (Aldrich) by ${ }^{1} \mathrm{H}$ and ${ }^{13} \mathrm{C}$ NMR spectra.

2-Phenylpyridine (Table 1, entry 5). Procedure A was followed using 2-chloropyridine (94 mg, $0.816 \mathrm{mmol})$ and phenyltributyltin $(0.30 \mathrm{~mL}, 0.898 \mathrm{mmol})$. The reaction mixture was purified by column chromatography on silica gel (10\% ethyl acetate/hexanes) to afford $108 \mathrm{mg}(85 \%)$ of the desired product as a light yellow liquid. The product was identical with an authentic material (Aldrich) by ${ }^{1} \mathrm{H}$ and ${ }^{13} \mathrm{C}$ NMR spectra. 
3-Phenylpyridine (Table 1, entry 6). Procedure A was followed using 3-chloropyridine (94 mg, $0.816 \mathrm{mmol})$ and phenyltributyltin $(0.30 \mathrm{~mL}, 0.898 \mathrm{mmol})$. The reaction mixture was purified by column chromatography on silica gel (30\% ethyl acetate/hexanes) to afford $126 \mathrm{mg}(99 \%)$ of the desired product as a light yellow liquid. The product was identical with an authentic material (Aldrich) by ${ }^{1} \mathrm{H}$ and ${ }^{13} \mathrm{C}$ NMR spectra.

2-Allyl-p-xylene ${ }^{8}$ (Table 1, entry 7). Procedure A was followed using 2-chloro-p-xylene $(116 \mathrm{mg}, 0.816 \mathrm{mmol})$ and allyltributyltin $(0.31 \mathrm{~mL}, 0.898 \mathrm{mmol})$ The reaction mixture was purified by column chromatography on silica gel (hexanes) to afford $113 \mathrm{mg}(95 \%)$ of the mixture of the desired product with its double bond migrating isomer as a colorless liquid. The ${ }^{1} \mathrm{H}$ and ${ }^{13} \mathrm{C}$ NMR spectra were in accordance with those described in the literature.

2,6-Dimethylbiphenyl ${ }^{1}$ (Table 1, entry 8). Procedure A was followed using 2-chloro-mxylene $(118 \mathrm{mg}, 0.816 \mathrm{mmol})$ and phenyltributyltin $(0.30 \mathrm{~mL}, 0.898 \mathrm{mmol})$. The reaction mixture was purified by column chromatography on silica gel (hexanes) to afford $141 \mathrm{mg}$ (95\%) of the desired product as a colorless liquid. The ${ }^{1} \mathrm{H}$ and ${ }^{13} \mathrm{C}$ NMR spectra were in accordance with those described in the literature.

4-Methoxybiphenyl (Table 1, entry 9). Procedure A was followed using 4-chloroanisole (117 $\mathrm{mg}, 0.816 \mathrm{mmol})$ and phenyltributyltin $(0.30 \mathrm{~mL}, 0.898 \mathrm{mmol})$. The reaction mixture was purified by column chromatography on silica gel ( $1 \%$ ethyl ether/pentane) to afford $107 \mathrm{mg}(71 \%)$ of the desired product as a white solid. The product was identical with an authentic material (Aldrich) by ${ }^{1} \mathrm{H}$ and ${ }^{13} \mathrm{C}$ NMR spectra.

1-(1'-Ethoxyvinyl)-4-methoxybenzene ${ }^{1}$ (Table 1, entry 10). Procedure A was followed using 4-chloroanisole (117 mg, $0.816 \mathrm{mmol})$ and 1-ethoxyvinyltributyltin $(0.34 \mathrm{~mL}$, 
$0.898 \mathrm{mmol})$. The reaction mixture was purified by column chromatography on silica gel (2.5\% triethylamine/hexanes) to afford $141 \mathrm{mg}(97 \%)$ of the desired product as a light yellow liquid. The ${ }^{1} \mathrm{H}$ and ${ }^{13} \mathrm{C}$ NMR spectra were in accordance with those described in the literature.

2-Cyanobiphenyl ${ }^{9}$ (Table 1, entry 11). Procedure A was followed using 2chlorobenzonitrile $(114 \mathrm{mg}, 0.816 \mathrm{mmol})$ and phenyltributyltin $(0.30 \mathrm{~mL}, 0.898 \mathrm{mmol})$. The reaction mixture was purified by column chromatography on silica gel (4\% ethyl acetate/hexanes) to afford $135 \mathrm{mg}(91 \%)$ of the desired product as a colorless liquid. The ${ }^{1} \mathrm{H}$ and ${ }^{13} \mathrm{C}$ NMR spectra were in accordance with those described in the literature.

Methyl 4-phenylbenzoate ${ }^{10}$ (Table 2, entry 1). Procedure B was followed using methyl4-chlorobenzoate $(142 \mathrm{mg}, 0.816 \mathrm{mmol})$ and phenyltributyltin $(0.30 \mathrm{~mL}, 0.898 \mathrm{mmol})$. The reaction mixture was purified by column chromatography on silica gel (2\% ethyl acetate/hexanes) to afford $164 \mathrm{mg}(95 \%)$ of the desired product as white solid. The ${ }^{1} \mathrm{H}$ and ${ }^{13} \mathrm{C}$ NMR spectra were in accordance with those described in the literature.

4-Nitrobiphenyl ${ }^{7}$ (Table 2, entry 2). Procedure B was followed using 1-chloro-4nitrobenzene $(130 \mathrm{mg}, 0.816 \mathrm{mmol})$ and phenyltributyltin $(0.30 \mathrm{~mL}, 0.898 \mathrm{mmol})$. The reaction mixture was purified by column chromatography on silica gel ( $2 \%$ ethyl acetate/hexanes) to afford $158 \mathrm{mg}(98 \%)$ of the desired product as a light yellow solid. The ${ }^{1} \mathrm{H}$ and ${ }^{13} \mathrm{C}$ NMR spectra were in accordance with those described in the literature.

4-Phenylbenzaldehyde (Table 2, entry 3). Procedure B was followed using 4chlorobenzaldehyde (118 mg, $0.816 \mathrm{mmol})$ and phenyltributyltin $(0.30 \mathrm{~mL}, 0.898 \mathrm{mmol})$. The reaction mixture was purified by column chromatography on silica gel (3\% ethyl acetate/hexanes) to afford $138 \mathrm{mg}(93 \%)$ of the desired product as a white solid. The 
product was identical with an authentic material (Aldrich) by ${ }^{1} \mathrm{H}$ and ${ }^{13} \mathrm{C}$ NMR spectra.

4-Phenylbenzophenone (Table 2, entry 4). Procedure B was followed using 4chlorobenzophenone $(179 \mathrm{mg}, 0.816 \mathrm{mmol})$ and phenyltributyltin $(0.30 \mathrm{~mL}, 0.898$ mmol). The reaction mixture was purified by column chromatography on silica gel ( $3 \%$ ethyl acetate/hexanes) to afford $207 \mathrm{mg}(98 \%)$ of the desired product as a white solid. The product was identical with an authentic material (Aldrich) by ${ }^{1} \mathrm{H}$ and ${ }^{13} \mathrm{C} \mathrm{NMR}$ spectra.

4-Cyanobiphenyl ${ }^{7}$ (Table 2, entry 5). Procedure B was followed using 4chlorobenzonitrile $(114 \mathrm{mg}, 0.816 \mathrm{mmol})$ and phenyltributyltin $(0.30 \mathrm{~mL}, 0.898 \mathrm{mmol})$. The reaction mixture was purified by column chromatography on silica gel $(2 \%$ ethyl acetate/hexanes) to afford $143 \mathrm{mg}(98 \%)$ of the desired product as a white solid. The ${ }^{1} \mathrm{H}$ and ${ }^{13} \mathrm{C}$ NMR spectra were in accordance with those described in the literature.

4-Trifluoromethylbiphenyl ${ }^{7}$ (Table 2, entry 6). Procedure B was followed using 4chlorobenzotrifluoride $(150 \mathrm{mg}, 0.816 \mathrm{mmol})$ and phenyltributyltin $(0.30 \mathrm{~mL}, 0.898$ mmol). The reaction mixture was purified by column chromatography on silica gel (hexanes) to afford $180 \mathrm{mg}(99 \%)$ of the desired product as a white solid. The ${ }^{1} \mathrm{H}$ and ${ }^{13} \mathrm{C}$ NMR spectra were in accordance with those described in the literature.

Methyl-3-phenylbenzoate ${ }^{11}$ (Table 2, entry 7). Procedure B was followed using methyl3-chlorobenzoate $(142 \mathrm{mg}, 0.816 \mathrm{mmol})$ and phenyltributyltin $(0.30 \mathrm{~mL}, 0.898 \mathrm{mmol})$. The reaction mixture was purified by column chromatography on silica gel $(2 \%$ ethyl acetate/hexanes) to afford $164 \mathrm{mg}(95 \%)$ of the desired product as a colorless liquid. The ${ }^{1} \mathrm{H}$ and ${ }^{13} \mathrm{C}$ NMR spectra were in accordance with those described in the literature.

4-Methoxybiphenyl (Table 3, entry 1). Procedure B was followed using 4-chloroanisole 
(117 mg, $0.816 \mathrm{mmol})$, phenyltributyltin $(0.30 \mathrm{~mL}, 0.898 \mathrm{mmol})$, and $4(12.7 \mathrm{mg}, 0.029$ mmol, $3.5 \mathrm{~mol} \%$ ). The reaction mixture was purified by column chromatography on silica gel (1\% ethyl ether/pentane) to afford $131 \mathrm{mg}(87 \%)$ of the desired product as a white solid. The product was identical with an authentic material (Aldrich) by ${ }^{1} \mathrm{H}$ and ${ }^{13} \mathrm{C}$ NMR spectra.

2,5-Dimethylbiphenyl ${ }^{12}$ (Table 3, entry 2). Procedure B was followed using 2-chloro- $p$ xylene (116 mg, $0.816 \mathrm{mmol})$, phenyltributyltin $(0.30 \mathrm{ml}, 0.898 \mathrm{mmol})$, and $4(12.7 \mathrm{mg}$, $0.029 \mathrm{mmol}, 3.5 \mathrm{~mol} \%)$. The reaction mixture was purified by column chromatography on silica gel (hexanes) to afford $127 \mathrm{mg}(85 \%)$ of the desired product as a colorless liquid. The ${ }^{1} \mathrm{H}$ and ${ }^{13} \mathrm{C}$ NMR spectra were in accordance with those described in the literature.

3,4-Methylenedioxybiphenyl ${ }^{13}$ (Table 3, entry 3). Procedure B was followed using 5chloro-1,3-benzodioxole $(130 \mathrm{mg}, 0.816 \mathrm{mmol})$, phenyltributyltin $(0.30 \mathrm{~mL}, 0.898$ $\mathrm{mmol})$, and 4 (12.7 $\mathrm{mg}, 0.029 \mathrm{mmol}, 3.5 \mathrm{~mol} \%)$. The reaction mixture was purified by column chromatography on silica gel (1\% ethyl ether/pentane) to afford $146 \mathrm{mg}(90 \%)$ of the desired product as a colorless liquid.

${ }^{1} \mathrm{H}$ NMR (300 MHz, $\left.\mathrm{CDCl}_{3}\right): \delta$ 7.54-7.51 (m, 2H), 7.44-7.42 (m, 2H), 7.39-7.31 (m, 1H), $7.08(\mathrm{~m}, 2 \mathrm{H}), 6.00(\mathrm{~s}, 2 \mathrm{H}) .{ }^{13} \mathrm{C} \mathrm{NMR}\left(75.5 \mathrm{MHz}, \mathrm{CDCl}_{3}\right): \delta 148.3,147.3,141.1,135.8$ 128.9, 127.1, 127.1, 120.8, 108.8, 107.9, 101.3.

3-Phenylpyridine (Table 3, entry 4). Procedure B was followed using 3-chloropyridine (94 mg, $0.816 \mathrm{mmol})$, phenyltributyltin $(0.30 \mathrm{~mL}, 0.898 \mathrm{mmol})$, and $4(12.7 \mathrm{mg}, 0.029$ mmol, $3.5 \mathrm{~mol} \%)$. The reaction mixture was purified by column chromatography on silica gel (30\% ethyl acetate/hexanes) to afford $123 \mathrm{mg}(97 \%)$ of the desired product as a 
light yellow liquid. The product was identical with an authentic material (Aldrich) by ${ }^{1} \mathrm{H}$ and ${ }^{13} \mathrm{C}$ NMR spectra.

2-Phenylpyridine (Table 3, entry 5). Procedure B was followed using 2-chloropyridine (94 mg, $0.816 \mathrm{mmol})$, phenyltributyltin $(0.30 \mathrm{~mL}, 0.898 \mathrm{mmol})$, and $4(12.7 \mathrm{mg}, 0.029$ mmol, $3.5 \mathrm{~mol} \%)$. The reaction mixture was purified by column chromatography on silica gel (10\% ethyl acetate/hexanes) to afford $81 \mathrm{mg}(64 \%)$ of the desired product as a light yellow liquid. The product was identical with an authentic material (Aldrich) by ${ }^{1} \mathrm{H}$ and ${ }^{13} \mathrm{C}$ NMR spectra.

3-Phenylthiophene (Table 3, entry 6). Procedure $B$ was followed using 3chlorothiophene (94 $\mathrm{mg}, 0.816 \mathrm{mmol})$, phenyltributyltin $(0.30 \mathrm{~mL}, 0.898 \mathrm{mmol})$, and 1 (16.8 $\mathrm{mg}, 0.048 \mathrm{mmol}, 6 \mathrm{~mol} \%$ ). The reaction mixture was purified by column chromatography on silica gel (hexanes) to afford $91 \mathrm{mg}(69 \%)$ of the desired product as a white solid. The product was identical with an authentic material (Aldrich) by ${ }^{1} \mathrm{H}$ and ${ }^{13} \mathrm{C}$ NMR spectra.

4-Vinylanisole (Table 4, entry 1). Procedure B was followed using 4-chloro-anisole (117 $\mathrm{mg}, 0.816 \mathrm{mmol})$, vinyltributyltin $(0.27 \mathrm{~mL}, 0.898 \mathrm{mmol})$, and $4(12.7 \mathrm{mg}, 0.029 \mathrm{mmol}$, $3.5 \mathrm{~mol} \%)$. The reaction mixture was purified by column chromatography on silica gel (1\% ethyl ether/pentane) to afford $62 \mathrm{mg}(57 \%)$ of the desired product as a colorless liquid. The product was identical with an authentic material (Aldrich) by ${ }^{1} \mathrm{H}$ and ${ }^{13} \mathrm{C}$ NMR spectra.

1-(1'-Ethoxyvinyl)-4-methoxybenzene ${ }^{1}$ (Table 4, entry 2). Procedure B was followed using 4-chloroanisole (117 mg, $0.816 \mathrm{mmol}), 1$-ethoxyvinyltributyltin $(0.34 \mathrm{~mL}, 0.898$ $\mathrm{mmol})$, and $4(12.7 \mathrm{mg}, 0.029 \mathrm{mmol}, 3.5 \mathrm{~mol} \%)$. The reaction mixture was purified by 
column chromatography on silica gel (2.5\% triethylamine/hexanes) to afford $139 \mathrm{mg}$ (96\%) of the desired product as a light yellow liquid. The ${ }^{1} \mathrm{H}$ and ${ }^{13} \mathrm{C}$ NMR spectra were in accordance with those described in the literature.

4-Allylanisole (Table 4, entry 3). Procedure B was followed using 4-chloroanisole (117 $\mathrm{mg}, 0.816 \mathrm{mmol})$, allyltributyltin $(0.31 \mathrm{~mL}, 0.898 \mathrm{mmol})$, and $4(12.7 \mathrm{mg}, 0.029 \mathrm{mmol}$, $3.5 \mathrm{~mol} \%)$. The reaction mixture was purified by column chromatography on silica gel (1\% ethyl ether/pentane) to afford $116 \mathrm{mg}(95 \%)$ of the mixture of the desired product with its double bond migrating isomer as a colorless liquid. The product was identical with an authentic material (Aldrich) by ${ }^{1} \mathrm{H}$ and ${ }^{13} \mathrm{C}$ NMR spectra.

2-(4'-Methoxyphenyl)thiophene ${ }^{14}$ (Table 4, entry 4). Procedure B was followed using 4-chloroanisole (117 mg, $0.816 \mathrm{mmol})$, (tributylstannyl)thiophene $(0.27 \mathrm{~mL}, 0.898$ mmol), and 4 (12.7 mg, $0.029 \mathrm{mmol}, 3.5 \mathrm{~mol} \%$ ). The reaction mixture was purified by column chromatography on silica gel (1\% ethyl ether/pentane) to afford $105 \mathrm{mg}(67 \%)$ of the desired product as a white solid. The ${ }^{1} \mathrm{H}$ and ${ }^{13} \mathrm{C}$ NMR spectra were in accordance with those described in the literature.

2-(4'-Methoxyphenyl)furan ${ }^{15}$ (Table 4, entry 5). Procedure B was followed using 4chloroanisole (117 mg, $0.816 \mathrm{mmol})$, (tributylstannyl)furan $(0.27 \mathrm{~mL}, 0.898 \mathrm{mmol})$, and 4 (12.7 mg, $0.029 \mathrm{mmol}, 3.5 \mathrm{~mol} \%$ ). The reaction mixture was purified by column chromatography on silica gel (1\% ethyl acetate /hexanes) to afford $140 \mathrm{mg}(97 \%)$ of the desired product as a white solid. The ${ }^{1} \mathrm{H}$ and ${ }^{13} \mathrm{C}$ NMR spectra were in accordance with those described in the literature.

2,5,2'-Trimethylbiphenyl ${ }^{16}$ (Table 5, entry 1). Procedure C was followed using 2chloro-p-xylene (71 $\mathrm{mg}, 0.5 \mathrm{mmol})$ and $o$-tolyltributylstannane $(210 \mathrm{mg}, 0.55 \mathrm{mmol})$. 
After the reaction was run for $48 \mathrm{~h}$, the reaction mixture was purified by column chromatography on silica gel (hexanes) to afford $97 \mathrm{mg}$ (99\%) of the desired product as a colorless liquid.

${ }^{1} \mathrm{H}$ NMR $\left(300 \mathrm{MHz}, \mathrm{CDCl}_{3}\right): \delta$ 7.31-7.24 (m, 3H), 7.22-7.11 (m, 3H), $6.99(\mathrm{~s}, 1 \mathrm{H}), 2.39$ (s, 3H), $2.12(\mathrm{~s}, 3 \mathrm{H}), 2.07$ (s, 3H). ${ }^{13} \mathrm{C} \mathrm{NMR}\left(75.5 \mathrm{MHz}, \mathrm{CDCl}_{3}\right): \delta 142.0,141.7,136.0$, 135.1, 132.9, 130.2, 130.0, 129.9, 129.5, 128.1, 127.3, 125.8, 21.2, 20.1, 19.6.

2,4,6,2',5'-Pentamethylbiphenyl (Table 5, entry 2). Procedure C was followed using 2chloro-p-xylene (71 mg, $0.5 \mathrm{mmol})$ and 2-mesityltributylstannane $(225 \mathrm{mg}, 0.55 \mathrm{mmol})$. After the reaction was run for $48 \mathrm{~h}$, the reaction mixture was purified by column chromatography on silica gel (hexanes) to afford $98 \mathrm{mg}(88 \%)$ of the desired product as a colorless liquid.

${ }^{1} \mathrm{H}$ NMR (300 MHz, $\left.\mathrm{CDCl}_{3}\right): \delta 7.18(\mathrm{~d}, J=7.7 \mathrm{~Hz}, 1 \mathrm{H}), 7.07(\mathrm{~d}, J=7.7 \mathrm{~Hz}, 1 \mathrm{H}), 6.95(\mathrm{~s}$, 2H), $6.85(\mathrm{~s}, 1 \mathrm{H}), 2.35(\mathrm{~s}, 6 \mathrm{H}), 1.94(\mathrm{~s}, 9 \mathrm{H}) .{ }^{13} \mathrm{C} \mathrm{NMR}\left(75.5 \mathrm{MHz}, \mathrm{CDCl}_{3}\right): \delta$ 140.6, 138.6, 136.4, 135.9, 132.8, 129.9, 128.2, 127.8, 21.3, 21.3, 20.5, 19.2. HRMS $m / z$ Calcd for $\mathrm{C}_{17} \mathrm{H}_{20}: 224.15650$. Found 224.15692.

2,6,2'-Trimethylbiphenyl ${ }^{1}$ (Table 5, entry 3). Procedure $C$ was followed using 2-chloro$m$-xylene (72.5 mg, $0.5 \mathrm{mmol})$ and $o$-tolyltributylstannane $(210 \mathrm{mg}, 0.55 \mathrm{mmol})$. After the reaction was run for $60 \mathrm{~h}$, the reaction mixture was purified by column chromatography on silica gel (hexanes) to afford $95 \mathrm{mg}$ (97\%) of the desired product as a colorless liquid. The ${ }^{1} \mathrm{H}$ and ${ }^{13} \mathrm{C}$ NMR spectra were in accordance with those described in the literature.

2,4,6,2',6'-Pentamethylbiphenyl ${ }^{1}$ (Table 5, entry 4). Procedure $C$ was followed using 2-chloro- $m$-xylene $(72.5 \mathrm{mg}, 0.5 \mathrm{mmol})$ and 2-mesityltributylstannane $(225 \mathrm{mg}, 0.55$ 
mmol). After the reaction was run for $60 \mathrm{~h}$, the reaction mixture was purified by column chromatography on silica gel (hexanes) to afford $91 \mathrm{mg}(81 \%)$ of the desired product as a colorless liquid. The ${ }^{1} \mathrm{H}$ and ${ }^{13} \mathrm{C}$ NMR spectra were in accordance with those described in the literature.

1-(2'-Methylphenyl)naphthalene ${ }^{17}$ (Table 5, entry 5). Procedure $\mathrm{C}$ was followed using 1-chloronaphthalene $(90 \mathrm{mg}, 0.5 \mathrm{mmol})$ and $o$-tolyltributylstannane $(210 \mathrm{mg}, 0.55$ mmol). After the reaction was run for $40 \mathrm{~h}$, the reaction mixture was purified by column chromatography on silica gel (hexanes) to afford $107 \mathrm{mg}(98 \%)$ of the mixture of the desired product with 2-(2'-Methylphenyl)naphthalene (which came from 2chloronaphthalene in the starting material) as a colorless liquid. The ${ }^{1} \mathrm{H}$ and ${ }^{13} \mathrm{C} \mathrm{NMR}$ spectra were in accordance with those described in the literature.

1-(2',4',6'-Trimethylphenyl)naphthalene ${ }^{18}$ (Table 5, entry 6). Procedure C was followed using 1-chloronaphthalene $(90 \mathrm{mg}, 0.5 \mathrm{mmol})$ and 2-mesityltributylstannane (225 $\mathrm{mg}, 0.55 \mathrm{mmol}$ ). After the reaction was run for $40 \mathrm{~h}$, the reaction mixture was purified by column chromatography on silica gel (hexanes) to afford $119 \mathrm{mg}(97 \%)$ of the mixture of the desired product with 2-(2',4',6'-Trimethylphenyl)naphthalene (which came from 2-chloronaphthalene in the starting material) as a colorless liquid.

${ }^{1} \mathrm{H}$ NMR $\left(300 \mathrm{MHz}, \mathrm{CDCl}_{3}\right): \delta$ 7.95-7.65 (m, 2H), 7.57-7.50 (m, 2H), 7.39-7.29 (m, 3H), $7.05(\mathrm{~s}, 2 \mathrm{H}), 2.43(\mathrm{~s}, 3 \mathrm{H}), 1.92(\mathrm{~s}, 6 \mathrm{H}) .{ }^{13} \mathrm{C} \mathrm{NMR}\left(75.5 \mathrm{MHz}, \mathrm{CDCl}_{3}\right): \delta$ 139.0, 137.1, $137.06,136.9,133.9,132.2,128.3,127.3,126.9,126.2,125.9,125.7,21.4,20.5$.

2-Methyl-1-(2'-methylphenyl)naphthalene ${ }^{19}$ (Table 5, entry 7) Procedure C was followed using 1-bromo-2-methyl-naphthalene $(123 \mathrm{mg}, \quad 0.5 \mathrm{mmol})$ and $o$ tolyltributylstannane $(210 \mathrm{mg}, 0.55 \mathrm{mmol})$. After the reaction was run for $48 \mathrm{~h}$, the 
reaction mixture was purified by column chromatography on silica gel (hexanes) to afford $99 \mathrm{mg}(86 \%)$ of the desired product as a colorless liquid.

${ }^{1} \mathrm{H}$ NMR $\left(300 \mathrm{MHz}, \mathrm{CDCl}_{3}\right): \delta 7.86(\mathrm{~d}, J=7.9 \mathrm{~Hz}, 1 \mathrm{H}), 7.81(\mathrm{~d}, J=8.4 \mathrm{~Hz}, 1 \mathrm{H}), 7.46-$ $7.25(\mathrm{~m}, 7 \mathrm{H}), 7.14(\mathrm{~d}, J=6.7 \mathrm{~Hz}, 1 \mathrm{H}), 2.19(\mathrm{~s}, 3 \mathrm{H}), 1.94(\mathrm{~s}, 3 \mathrm{H}) .{ }^{13} \mathrm{C} \mathrm{NMR}(75.5 \mathrm{MHz}$, $\left.\mathrm{CDCl}_{3}\right): \delta 139.4,137.7,137.0,133.3,132.7,132.2,130.2,130.2,128.8,128.1,127.6$ $127.3,126.2,126.1,125.9,124.9,20.6,19.8$.

2-Methyl-1-(2',4',6'-trimethylphenyl)naphthalene (Table 5, entry 7). Procedure C was followed using 1-bromo-2-methyl-naphthalene (123 mg, $0.5 \mathrm{mmol})$ and 2mesityltributylstannane $(225 \mathrm{mg}, 0.55 \mathrm{mmol})$. After the reaction was run for $48 \mathrm{~h}$, the reaction mixture was purified by column chromatography on silica gel (hexanes) to afford $100 \mathrm{mg}(77 \%)$ of the desired product as a colorless liquid.

${ }^{1} \mathrm{H}$ NMR $\left(300 \mathrm{MHz}, \mathrm{CDCl}_{3}\right): \delta 7.86(\mathrm{~d}, J=8.1 \mathrm{~Hz}, 1 \mathrm{H}), 7.79(\mathrm{~d}, J=8.3 \mathrm{~Hz}, 1 \mathrm{H}), 7.46-$ $7.38(\mathrm{~m}, 2 \mathrm{H}), 7.34-7.22(\mathrm{~m}, 2 \mathrm{H}), 7.04(\mathrm{~s}, 2 \mathrm{H}), 2.41(\mathrm{~s}, 3 \mathrm{H}), 2.14(\mathrm{~s}, 3 \mathrm{H}), 1.81(\mathrm{~s}, 6 \mathrm{H}) .{ }^{13} \mathrm{C}$ NMR $\left(75.5 \mathrm{MHz}, \mathrm{CDCl}_{3}\right): \delta 136.8,136.7,135.7,133.3,132.45,132.40,128.9,128.4$, 128.1, 127.1, 126.2, 125.3, 125.0, 21.4, 20.1, 20.0. HRMS $m / z$ Calcd for $\mathrm{C}_{20} \mathrm{H}_{20}$ : 260.1565. Found: 260.1572 .

2,4,6-Triisopropyl-2'-methylbiphenyl ${ }^{20}$ (Table 5, entry 9). Procedure C was followed using 1-bromo-2,4,6-triisopropylbenzene (142 $\mathrm{mg}, 0.5 \mathrm{mmol})$, o-tolyltributylstannane (210 mg, $0.55 \mathrm{mmol}), 3$ (14.4 mg, $0.035 \mathrm{mmol}, 7 \mathrm{~mol} \%$ ), and $\operatorname{Pd}_{2}(\mathrm{dba})_{3}(13.7 \mathrm{mg}, 0.015$ mmol, $3 \mathrm{~mol} \%$ ). After the reaction was run for $60 \mathrm{~h}$, the reaction mixture was purified by column chromatography on silica gel (hexanes) to afford $130 \mathrm{mg}(88 \%)$ of the desired product as a white solid.

${ }^{1} \mathrm{H}$ NMR $\left(300 \mathrm{MHz}, \mathrm{CDCl}_{3}\right): \delta$ 7.27-7.19 (m, 3H), 7.08-7.05 (m, 3H), 2.95 (septet, $J=$ 
$7.0 \mathrm{~Hz}, 1 \mathrm{H}), 2.44$ (septet, $J=6.8 \mathrm{~Hz}, 2 \mathrm{H}), 2.00$ (s, 3H), 1.31 (d, $J=7.0 \mathrm{~Hz}, 6 \mathrm{H}), 1.12$ (d, $J=7.0 \mathrm{~Hz}, 6 \mathrm{H}), 1.03(\mathrm{~d}, J=6.8 \mathrm{~Hz}, 6 \mathrm{H}) .{ }^{13} \mathrm{C} \mathrm{NMR}\left(75.5 \mathrm{MHz}, \mathrm{CDCl}_{3}\right): \delta 147.9,146.3$, 140.4, 136.9, 136.0, 130.3, 129.7, 126.9, 125.5, 120.8, 34.4, 30.5, 25.1, 24.3, 23.7, 20.5. HRMS m/z Calcd for $\mathrm{C}_{22} \mathrm{H}_{30}$ : 294.2347. Found: 294.2350.

4-tert-Butylstyrene (Table 6, entry 1). Procedure D was followed using 1-bromo-4-tertbutylbenzene (177 $\mathrm{mg}, 0.816 \mathrm{mmol})$ and vinyltributyltin $(0.27 \mathrm{ml}, 0.898 \mathrm{mmol})$. After the reaction was run for $10 \mathrm{~h}$, the reaction mixture was purified by column chromatography on silica gel (hexanes) to afford $129 \mathrm{mg}(99 \%)$ of the desired product as a colorless liquid. The product was identical with an authentic material (Aldrich) by ${ }^{1} \mathrm{H}$ and ${ }^{13} \mathrm{C}$ NMR spectra.

4-Allyl-tert-butylbenzene ${ }^{21}$ (Table 6, entry 2). Procedure D was followed using 1bromo-4-tert-butylbenzene $(177 \mathrm{mg}, 0.816 \mathrm{mmol})$ and allyltributyltin $(0.31 \mathrm{~mL}, 0.898$ mmol). After the reaction was run for $10 \mathrm{~h}$, the reaction mixture was purified by column chromatography on silica gel (hexanes) to afford $124 \mathrm{mg}(87 \%)$ of the desired product as a colorless liquid. The ${ }^{1} \mathrm{H}$ and ${ }^{13} \mathrm{C}$ NMR spectra were in accordance with those described in the literature.

2-(4'-tert-Butylphenyl)furan ${ }^{22}$ (Table 6, entry 3). Procedure D was followed using 1bromo-4-tert-butylbenzene $(177 \mathrm{mg}, 0.816 \mathrm{mmol})$ and (tributylstannyl)furan $(0.27 \mathrm{~mL}$, $0.898 \mathrm{mmol}$ ). After the reaction was run for $10 \mathrm{~h}$, the reaction mixture was purified by column chromatography on silica gel (hexanes) to afford $157 \mathrm{mg}(97 \%)$ of the desired product as a colorless liquid.

${ }^{1} \mathrm{H}$ NMR (300 MHz, $\left.\mathrm{CDCl}_{3}\right): \delta 7.64(\mathrm{~d}, J=6.6 \mathrm{~Hz}, 2 \mathrm{H}), 7.63-7.42(\mathrm{~m}, 3 \mathrm{H}), 6.63(\mathrm{~d}, J=$ $3.3 \mathrm{~Hz}, 1 \mathrm{H}), 6.49-6.47$ (m, 1H), 1.367 (s, 9H). ${ }^{13} \mathrm{C}$ NMR (75.5 MHz, $\left.\mathrm{CDCl}_{3}\right): 154.4$, 
$150.6,141.9,128.4,125.8,123.8,111.7,104.5,34.8,31.5$.

4-tert-Butylbiphenyl ${ }^{23}$ (Table 6, entry 4). Procedure D was followed using 1-bromo-4tert-butylbenzene (177 mg, $0.816 \mathrm{mmol})$ and tributylphenyltin $(0.30 \mathrm{~mL}, 0.898 \mathrm{mmol})$. After the reaction was run for $10 \mathrm{~h}$, the reaction mixture was purified by column chromatography on silica gel (hexanes) to afford $168 \mathrm{mg}(98 \%)$ of the desired product as a white solid. The ${ }^{1} \mathrm{H}$ and ${ }^{13} \mathrm{C}$ NMR spectra were in accordance with those described in the literature.

3-Methyl-4-vinyl-anisole ${ }^{24}$ (Table 6, entry 5). Procedure D was followed using 4bromo-3-methylanisole $(167 \mathrm{mg}, 0.816 \mathrm{mmol}$ and vinyltributyltin $(0.27 \mathrm{~mL}, 0.898$ mmol). After the reaction was run for $14 \mathrm{~h}$, the reaction mixture was purified by column chromatography on silica gel (1\% ethyl ether/pentane) to afford $117 \mathrm{mg}(97 \%)$ of the desired product as a pale yellow liquid.

${ }^{1} \mathrm{H}$ NMR $\left(300 \mathrm{MHz}, \mathrm{CDCl}_{3}\right): \delta 7.45(\mathrm{~d}, J=8.4 \mathrm{~Hz}, 1 \mathrm{H}), 6.90(\mathrm{dd}, J=17.5,11.0 \mathrm{~Hz}, 1 \mathrm{H})$, 6.77-6.71 (m, 2H), $5.56(\mathrm{dd}, J=17.4,1.3 \mathrm{~Hz}, 1 \mathrm{H}), 5.20(\mathrm{dd}, J=10.9,1.3 \mathrm{~Hz}), 3.81(\mathrm{~s}$, 3H), $2.36(\mathrm{~s}, 3 \mathrm{H}) .{ }^{13} \mathrm{C}$ NMR $\left(75.5 \mathrm{MHz}, \mathrm{CDCl}_{3}\right): \delta 159.3,137.1,134.3,129.8,126.7$, $115.6,113.3,111.8,55.4,20.2$.

3-Methyl-4-allyl-anisole (Table 6, entry 6). Procedure D was followed using 4-bromo3-methylanisole $(167 \mathrm{mg}, 0.816 \mathrm{mmol})$ and allylltributyltin $(0.31 \mathrm{~mL}, 0.898 \mathrm{mmol})$. After the reaction was run for $14 \mathrm{~h}$, the reaction mixture was purified by column chromatography on silica gel (1\% ethyl ether/pentane) to afford $128 \mathrm{mg}(97 \%)$ of the desired product as a colorless liquid.

${ }^{1} \mathrm{H}$ NMR $\left(300 \mathrm{MHz}, \mathrm{CDCl}_{3}\right): \delta 7.06(\mathrm{~d}, J=8.0 \mathrm{~Hz}, 1 \mathrm{H}), 6.74-6.69(\mathrm{~m}, 2 \mathrm{H}), 5.99-5.88(\mathrm{~m}$, 1H), 5.07-4.94 (m, 2H), $3.79(\mathrm{~s}, 3 \mathrm{H}), 3.32(\mathrm{~d}, J=6.2 \mathrm{~Hz}, 2 \mathrm{H}), 2.28(\mathrm{~s}, 3 \mathrm{H}) .{ }^{13} \mathrm{C} \mathrm{NMR}$ 
$\left(75.5 \mathrm{MHz}, \mathrm{CDCl}_{3}\right): \delta 158.2,137.8,137.3,130.5,130.3,116.0,115.5,111.2,55.4,37.1$, 19.8. HRMS $m / z$ Calcd for $\mathrm{C}_{11} \mathrm{H}_{14} \mathrm{O}: 162.10447$. Found: 162.10480 .

2-(2'-Methyl-4'-methoxyphenyl)furan (Table 6, entry 7). Procedure D was followed using 4-bromo-3-methylanisole (167 $\mathrm{mg}, 0.816 \mathrm{mmol})$ and (tributylstannyl)furan (0.27 $\mathrm{mL}, 0.898 \mathrm{mmol})$. After the reaction was run for $14 \mathrm{~h}$, the reaction mixture was purified by column chromatography on silica gel (1\% ethyl ether/pentane) to afford $150 \mathrm{mg}(98 \%)$ of the desired product as a colorless liquid.

${ }^{1} \mathrm{H}$ NMR $\left(300 \mathrm{MHz}, \mathrm{CDCl}_{3}\right): \delta 7.61(\mathrm{~d}, J=1.2 \mathrm{~Hz}, 1 \mathrm{H}), 7.59-7.47(\mathrm{~m}, 1 \mathrm{H}), 6.81-6.79(\mathrm{~m}$, 2H), 6.49-6.41 (m, 2H), $3.83(\mathrm{~s}, 3 \mathrm{H}), 2.47(\mathrm{~s}, 3 \mathrm{H}) .{ }^{13} \mathrm{C}$ NMR $\left(75.5 \mathrm{MHz}, \mathrm{CDCl}_{3}\right): \delta$ $159.0,153.3,141.3,136.6,141.3,136.6,128.8,123.6,116.6,111.5,111.4,107.3,55.5$, 22.2. HRMS $m / z$ Calcd for $\mathrm{C}_{12} \mathrm{H}_{12} \mathrm{O}_{2}: 188.0837$. Found: 188.0845 .

2-(2'-Methyl-4'-methoxyphenyl)thiophene (Table 6, entry 8). Procedure D was followed using 4-bromo-3-methylanisole $\left(\begin{array}{lllll}167 & \mathrm{mg}, & 0.816 & \mathrm{mmol}\end{array}\right)$ and (tributylstannyl)thiophene $(0.27 \mathrm{~mL}, 0.898 \mathrm{mmol})$. After the reaction was run at $50{ }^{\circ} \mathrm{C}$ for $14 \mathrm{~h}$, the reaction mixture was purified by column chromatography on silica gel (1\% ethyl ether/pentane) to afford $165 \mathrm{mg}(99 \%)$ of the desired product as a pale yellow liquid.

${ }^{1} \mathrm{H}$ NMR (300 MHz, $\left.\mathrm{CDCl}_{3}\right): \delta$ 7.37-7.30 (m, 2H), 7.11-7.08 (m, 1H), 7.03-7.02 (m, 1H), 6.85-6.77 (m, 2H), $3.84(\mathrm{~s}, 3 \mathrm{H}), 2.42(\mathrm{~s}, 3 \mathrm{H}) .{ }^{13} \mathrm{C} \mathrm{NMR}\left(75.5 \mathrm{MHz}, \mathrm{CDCl}_{3}\right): \delta$ 159.4, $143.3,137.9,131.9,127.2,127.0,126.3,124.9,116.3,111.4,55.5,21.6$. HRMS $m / z$ Calcd for $\mathrm{C}_{12} \mathrm{H}_{12} \mathrm{OS}: 204.0609$. Found: 206.0604 .

4-(N,N-dimethylamino)styrene ${ }^{25}$ (Table 6, entry 9). Procedure D was followed using 4bromo- $N, N$-dimethylaniline $(168 \mathrm{mg}, 0.816 \mathrm{mmol})$ and vinyltributyltin $(0.27 \mathrm{~mL}, 0.898$ 
mmol). After the reaction was run for $14 \mathrm{~h}$, the reaction mixture was purified by column chromatography on silica gel (2\% ethyl acetate/hexanes) to afford $117 \mathrm{mg}(97 \%)$ of the desired product as a pale yellow liquid. The ${ }^{1} \mathrm{H}$ and ${ }^{13} \mathrm{C}$ NMR spectra were in accordance with those described in the literature.

2-(4'-N,N-Dimethylaminophenyl)furan ${ }^{26}$ (Table 6, entry 10). Procedure D was followed using 4-bromo- $N, N$-dimethylaniline $\left(\begin{array}{llll}168 & \mathrm{mg}, & 0.816 & \mathrm{mmol}\end{array}\right)$ and (tributylstannyl)furan $(0.27 \mathrm{~mL}, 0.898 \mathrm{mmol})$. After the reaction was run for $14 \mathrm{~h}$, the reaction mixture was purified by column chromatography on silica gel ( $2 \%$ ethyl acetate/hexanes) to afford $142 \mathrm{mg}(93 \%)$ of the desired product as a white solid. The ${ }^{1} \mathrm{H}$ and ${ }^{13} \mathrm{C}$ NMR spectra were in accordance with those described in the literature.

2,2'-Bithiophene (Table 6, entry 11). Procedure D was followed using 2bromothiophene (136 mg, $0.816 \mathrm{mmol})$ and (tributylstannyl)thiophene $(0.27 \mathrm{~mL}, 0.898$ mmol). After the reaction was run at $50{ }^{\circ} \mathrm{C}$ for $30 \mathrm{~h}$, the reaction mixture was purified by column chromatography on silica gel (1\% ethyl ether/pentane) to afford $132 \mathrm{mg}(98 \%)$ of the desired product as a white solid. The product was identical with an authentic material (Aldrich) by ${ }^{1} \mathrm{H}$ and ${ }^{13} \mathrm{C}$ NMR spectra.

2-(2'-Thienyl)furan (Table 6, entry 12). Procedure D was followed using 2bromothiophene (136 $\mathrm{mg}, 0.816 \mathrm{mmol})$ and (tributylstannyl)furan $(0.27 \mathrm{~mL}, 0.898$ mmol). After the reaction was run at $50{ }^{\circ} \mathrm{C}$ for $30 \mathrm{~h}$, the reaction mixture was purified by column chromatography on silica gel (1\% ethyl ether/pentane) to afford $132 \mathrm{mg}(98 \%)$ of the desired product as a colorless liquid. The product was identical with an authentic material (Aldrich) by ${ }^{1} \mathrm{H}$ and ${ }^{13} \mathrm{C}$ NMR spectra.

2-Phenylthiophene (Table 6, entry 13). Procedure D was followed using 2- 
bromothiophene $(136 \mathrm{mg}, 0.816 \mathrm{mmol})$ and tributylphenyltin $(0.30 \mathrm{~mL}, 0.898 \mathrm{mmol})$. After the reaction was run at $50{ }^{\circ} \mathrm{C}$ for $30 \mathrm{~h}$, the reaction mixture was purified by column chromatography on silica gel (hexanes) to afford $119 \mathrm{mg}(91 \%)$ of the desired product as a white solid. The product was identical with an authentic material (Aldrich) by ${ }^{1} \mathrm{H}$ and ${ }^{13} \mathrm{C}$ NMR spectra.

\section{Room-Temperature Synthesis of 1-(2'-Methylphenyl)naphthalene ${ }^{17}$ using Ligand 3}

(eq 1). In a glove box, the Schlenk tube equipped with a stir bar was charged with $\mathrm{Pd}_{2}(\mathrm{dba})_{3}(7 \mathrm{mg}, 0.0075 \mathrm{mmol}, 1.5 \mathrm{~mol} \%), \mathrm{CsF}(168 \mathrm{mg}, 1.1 \mathrm{mmol})$, and $3(6.2 \mathrm{mg}$, $0.015 \mathrm{mmol}, 3 \mathrm{~mol} \%$ ). The tube was fitted with a rubber septum and removed out of the glove box. One $\mathrm{mL}$ of 1,4-dioxane, 1-bromonaphthalene (103.5 $\mathrm{mg}, 0.5 \mathrm{mmol}$ ), and $o$ tolyltributylstannane $(210 \mathrm{mg}, 0.55 \mathrm{mmol})$ were added successively using syringes. The tube was sealed with a Teflon screwcap. The reaction mixture was stirred at room temperature for $48 \mathrm{~h}$, and then diluted with ether, filtered, and concentrated in vacuo. The crude product was purified by column chromatography on silica gel (hexanes) to afford $88 \mathrm{mg}(81 \%)$ of the desired product as a white solid. The ${ }^{1} \mathrm{H}$ and ${ }^{13} \mathrm{C}$ NMR spectra were in accordance with those described in the literature.

Room-Temperature Synthesis of 2-Methyl-1-(2-methylphenyl)naphthalene ${ }^{19}$ (eq 2). The above procedure for eq 1 was followed with 1-bromo-2-methyl-naphthalene (123 $\mathrm{mg}, 0.5 \mathrm{mmol})$. The desired product was obtained in $57 \%$ yield $(66 \mathrm{mg})$. The ${ }^{1} \mathrm{H}$ and ${ }^{13} \mathrm{C}$ NMR spectra were in accordance with those described in the literature.

\section{Stille Cross-Coupling of 4-Bromoanisole with 4-(Tributylstannyl)nitrobenzene (eq}

3). In a glove box, the Schlenk tube equipped with a stir bar was charged with $\mathrm{PdCl}_{2}(2.7$ 
mg, $0.015 \mathrm{mmol}, 3 \mathrm{~mol} \%)$, CsF (168 mg, $1.1 \mathrm{mmol}), \mathrm{CuI}(3.8 \mathrm{mg}, 0.02 \mathrm{mmol})$, and ligand 4 (6.7 $\mathrm{mg}, 0.015 \mathrm{mmol}, 3 \mathrm{~mol} \%)$. The tube was fitted with a rubber septum and removed out of the glove box. One $\mathrm{mL}$ of anhydrous $\mathrm{DMF}$, 1-bromoanisole (94 mg, 0.5 mmol) and 4-(tributylstannyl)nitrobenzene $(0.195 \mathrm{~mL}, 0.55 \mathrm{mmol})$ were added successively using syringes. The tube was sealed with a Teflon screwcap. The reaction mixture was stirred at room temperature for $20 \mathrm{~h}$, and then diluted with ether, filtered, and concentrated in vacuo. The crude product was purified by column chromatography on silica gel (5\% ethyl acetate / hexanes) to afford $87 \mathrm{mg}(76 \%)$ of the desired product as a light yellow solid. The ${ }^{1} \mathrm{H}$ and ${ }^{13} \mathrm{C}$ NMR spectra were in accordance with those described in the literature. ${ }^{27}$

\section{Stille Cross-Coupling of 4-tert-Butylphenyltriflate with Tributylphenyltin using}

Ligands 1-4 (eq 4). In a glove box, the Schlenk tube equipped with a stir bar was charged with $\mathrm{Pd}_{2}(\mathrm{dba})_{3}(11.2 \mathrm{mg}, 0.012 \mathrm{mmol}, 1.5 \mathrm{~mol} \%$ ) and $\mathrm{CsF}(272 \mathrm{mg}, 1.8 \mathrm{mmol})$. The tube was fitted with a rubber septum and removed out of the glove box. One $\mathrm{mL}$ of 1,4-dioxane, ligand $\mathbf{1}$ (or $\mathbf{2}$ ) (solid ligands 3 and $\mathbf{4}$ were added inside the glove box), 4tert-butylphenyltriflate $(0.19 \mathrm{~mL}, 0.816 \mathrm{mmol})$, and tributylphenyltin $(0.30 \mathrm{~mL}, 0.898$ mmol) were added in turn to the Schlenk tube through rubber septum using syringes. The tube was sealed with a Teflon screwcap. The reaction mixture was stirred for 30 minutes at room temperature, then, heated with stirring at $90{ }^{\circ} \mathrm{C}$ for $36 \mathrm{~h}$. The reaction mixture was cooled to room temperature, diluted with ether, filtered, and concentrated in vacuo. The crude product was purified by column chromatography on silica gel (hexanes) to afford the desired product as a white solid. The ${ }^{1} \mathrm{H}$ and ${ }^{13} \mathrm{C}$ NMR spectra were in accordance with those described in the literature. ${ }^{23}$ 
Competition Experiment Between Aryl Triflate and Aryl Bromide (eq 5) In a glove box, the Schlenk tube equipped with a stir bar was charged with $\operatorname{Pd}_{2}\left(\mathrm{dba}_{3}(11.2 \mathrm{mg}\right.$, $0.012 \mathrm{mmol}, 1.5 \mathrm{~mol} \%), \mathrm{CsF}(272 \mathrm{mg}, 1.8 \mathrm{mmol})$, and 4 (10.9 mg, $0.024 \mathrm{mmol}, 3 \mathrm{~mol}$ $\%)$. The tube was fitted with a rubber septum and removed out of the glove box. One $\mathrm{mL}$ of 1,4-dioxane, 4-bromotoluene $(0.1 \mathrm{~mL}, 0.816 \mathrm{mmol})$, 4-tert-butylphenyl triflate $(0.19$ $\mathrm{mL}, 0.816 \mathrm{mmol})$, and tributylphenyltin $(0.27 \mathrm{~mL}, 0.816 \mathrm{mmol})$ were then added successively using syringes. The tube was sealed with a Teflon screwcap. The reaction mixture was stirred at room temperature for $16 \mathrm{~h}$, and then diluted with ether, filtered, and concentrated in vacuo. The crude product was purified by column chromatography on silica gel (hexanes) to afford $115 \mathrm{mg}(84 \%)$ of 4-methylbiphenyl as a white solid. The product was identical with an authentic material obtained from Aldrich by ${ }^{1} \mathrm{H}$ and ${ }^{13} \mathrm{C}$ NMR spectra.

Competition Experiment Between Aryl Triflate and Aryl Chloride (eq 6) In a glove box, the Schlenk tube equipped with a stir bar was charged with $\operatorname{Pd}_{2}(\mathrm{dba})_{3}(11.2 \mathrm{mg}$, $0.012 \mathrm{mmol}, 1.5 \mathrm{~mol} \%), \mathrm{CsF}(272 \mathrm{mg}, 1.8 \mathrm{mmol})$, and 4 (10.9 mg, $0.024 \mathrm{mmol}, 3 \mathrm{~mol}$ $\%)$. The tube was fitted with a rubber septum and removed out of the glove box. One $\mathrm{mL}$ of 1,4-dioxane, 4-chlorotoluene $(0.1 \mathrm{~mL}, 0.816 \mathrm{mmol})$, 4-tert-butylphenyltriflate $(0.19$ $\mathrm{mL}, 0.816 \mathrm{mmol})$ and tributylphenyltin $(0.27 \mathrm{~mL}, 0.816 \mathrm{mmol})$ were then added successively using syringes. The tube was sealed with a Teflon screwcap. The reaction mixture was initially stirred for 30 minutes at room temperature then heated with stirring at $90{ }^{\circ} \mathrm{C}$ for $36 \mathrm{~h}$. The reaction mixture was cooled to room temperature, diluted with ether, filtered, and concentrated in vacuo. The crude product was purified by column chromatography on silica gel (hexanes) to afford $163 \mathrm{mg}(95 \%)$ of 4-tert-butylbiphenyl 
as a white solid. The ${ }^{1} \mathrm{H}$ and ${ }^{13} \mathrm{C}$ NMR spectra were in accordance with those described in the literature. ${ }^{23}$

1-Phenylcyclopentene ${ }^{28}$ (Table 7, entry 1) Procedure B was followed using 1-chloro-1cyclopentene $(86 \mathrm{mg}, 0.816 \mathrm{mmol})$, tributylphenyltin $(0.30 \mathrm{~mL}, 0.898 \mathrm{mmol})$, and 4 (12.7 $\mathrm{mg}, 0.029 \mathrm{mmol}, 3.5 \mathrm{~mol} \%$ ). After the reaction was run at $100{ }^{\circ} \mathrm{C}$ for $40 \mathrm{~h}$, the crude product was purified by column chromatography on silica gel (pentane) to afford $117 \mathrm{mg}$ $(91 \%)$ of the desired product as a colorless liquid.

${ }^{1} \mathrm{H}$ NMR $\left(300 \mathrm{MHz}, \mathrm{CDCl}_{3}\right): \delta 7.46(\mathrm{~d}, J=7.2 \mathrm{~Hz}, 2 \mathrm{H}), 7.35-7.22(\mathrm{~m}, 3 \mathrm{H}), 6.20(\mathrm{t}, J=$ $1.95 \mathrm{~Hz}, 1 \mathrm{H}), 2.76-2.73(\mathrm{~m}, 2 \mathrm{H}), 2.57-2.52(\mathrm{~m}, 2 \mathrm{H}), 2.09-1.99(\mathrm{~m}, 2 \mathrm{H}) .{ }^{13} \mathrm{C}$ NMR $(75.5$ $\left.\mathrm{MHz}, \mathrm{CDCl}_{3}\right): \delta 142.6,137.0,128.5,127.0,126.3,125.8,33.6,33.4,23.6$.

1-(2'-Thienyl)cyclopentene ${ }^{29}$ (Table 7, entry 2) Procedure B was followed using 1chloro-1-cyclopentene (86 mg, $0.816 \mathrm{mmol})$, (tributylstannyl)thiophene $(0.27 \mathrm{~mL}, 0.898$ $\mathrm{mmol})$, and 4 (12.7 $\mathrm{mg}, 0.029 \mathrm{mmol}, 3.5 \mathrm{~mol} \%$ ). After the reaction was run at $100{ }^{\circ} \mathrm{C}$ for $40 \mathrm{~h}$, the crude product was purified by column chromatography on silica gel (pentane) to afford $102 \mathrm{mg}(83 \%)$ of the desired product as a colorless liquid.

${ }^{1} \mathrm{H}$ NMR (300 MHz, $\left.\mathrm{CDCl}_{3}\right): \delta$ 7.16-7.14 (m, 1H), 6.99-6.92 (m, 2H), 6.05-6.03 (m, 1H), 2.70-2.68 (m, 2H), 2.55-2.50 (m, 2H), 2.08-2.00 (m, 2H). ${ }^{13} \mathrm{C}$ NMR (75.5 MHz, $\left.\mathrm{CDCl}_{3}\right)$ : $\delta 141.5,136.9,127.4,126.0,123.9,123.5,34.5,33.5,23.6$.

1-(2'-Furyl)cyclopentene ${ }^{29}$ (Table 7, entry 3) Procedure B was followed using 1-chloro1-cyclopentene (86 mg, $0.816 \mathrm{mmol})$, (tributylstannyl)furan $(0.27 \mathrm{~mL}, 0.898 \mathrm{mmol})$, and $4(12.7 \mathrm{mg}, 0.029 \mathrm{mmol}, 3.5 \mathrm{~mol} \%)$. After the reaction was run at $100{ }^{\circ} \mathrm{C}$ for $40 \mathrm{~h}$, the crude product was purified by column chromatography on silica gel (pentane) to afford $101 \mathrm{mg}(93 \%)$ of the desired product as a colorless liquid. 
${ }^{1} \mathrm{H}$ NMR $\left(300 \mathrm{MHz}, \mathrm{CDCl}_{3}\right): \delta 7.35(\mathrm{~d}, J=1.4 \mathrm{~Hz}, 1 \mathrm{H}), 6.38-6.36(\mathrm{~m}, 1 \mathrm{H}), 6.17(\mathrm{~d}, J=$ $3.3 \mathrm{~Hz}, 1 \mathrm{H}), 6.09-6.08(\mathrm{~m}, 1 \mathrm{H}), 2.65-2.60(\mathrm{~m}, 2 \mathrm{H}), 2.59-2.49(\mathrm{~m}, 2 \mathrm{H}), 2.04-1.94(\mathrm{~m}, 2 \mathrm{H})$.

${ }^{13} \mathrm{C}$ NMR $\left(75.5 \mathrm{MHz}, \mathrm{CDCl}_{3}\right): \delta 152.8,141.7,133.1,125.1,111.1,106.0,33.4,32.6$, 23.5.

\section{References}

(1) Littke, A. F.; Schwarz, L.; Fu, G. C. J. Am. Chem. Soc. 2002, 124, 6343.

(2) Kosugi, M.; Miyajima, Y.; Nakanish, H.; Sano, H.; Migita, T. Bull. Chem. Soc. Jap. 1989, $62,3383$.

(3) Seganish, W. M.; Deshong, P. J. Org. Chem. 2004, 69, 1137.

(4) Thomas, E. W.; Cudahy, M. M.; Spilman, C. H.; Dinh, D. M.; Watkins, T. L.; Vidmar, T. J. J. Med. Chem. 1992, 35, 1233.

(5) Naiini, A. A.; Menge, W. M. P. B. Verkade, J. G. Inorg. Chem. 1991, 30, 5009.

(6) Bergmann, E. D.; Blum, J. J. Org. Chem. 1959, 24, 549.

(7) Zapf, A.; Beller, M. Chem. Eur. J. 2000, 6, 1830.

(8) Ochiai, M.; Fujita, E.; Arimoto, M.; Yamaguchi, H. Chemical \& Pharmaceutical Bulletin 1982, 30, 3994.

(9) Zanon, J.; Klapars, A.; Buchwald, S. L. J. Am. Chem. Soc. 2003, 125, 2890.

(10) Riggleman, S.; Deshong, P. J. Org. Chem. 2003, 68, 8106.

(11) Kang, S.-K.; Kim, J.-S.; Yoon, S.-K.; Lim, K,-H.; Yoon, S. S. Tetrahedron Lett. 1998, 39, 3011 .

(12) Rao, M. S. C.; Rao, G. S. K. Synthesis 1987, 231.

(13) Nakao, Y.; Oda, T.; Sahoo, A. K.; Hiyama, T. J. Organomet. Chem. 2003, 687, 570. 
(14) Takahashi, K.; Suzuki, T.; Akiyama, K.; Ikegami, Y.; Fukazawa, Y. J. Am. Chem. Soc. 1993, 113, 4576.

(15) Tanis, S. T.; Deaton, M. V.; Dixon, L. A.; Mcwilliams, M. C.; Raggon, J. W., Collins, M. A. J. Org. Chem. 1998, 63, 6914.

(16) Altenhoff, G.; Goddard, R.; Lehmann, C. W.; Glorius, F. Angew. Chem., Int. Ed. 2003, 42, 3690 .

(17) Terao, Y.; Wakhi, H.; Satoh, T.; Miura, M.; Nomura, M. J. Am. Chem. Soc. 2001, $123,10407$.

(18) Tamao, K.; Sumitani, K.; Kiso, Y.; Zembayashi, M.; Fujioka, A.; Kodama, S.; Nakajima, I.; Minato, A.; Kumada, M. Bull. Chem. Soc. Jap. 1976, 49, 1958.

(19) Riguet, E.; Alami, M.; Cahiez, G. J. Organometal. Chem. 2001, 624, 376.

(20) Walker, S. D.; Barder, T. E.; Martineli, J. R.; Buchwald, S. L. Angew. Chem., Int. Ed. 2004, 43, 1871.

(21) Fouquet, E.; Pereyre, M.; Rodriguez, A. L. J. Org. Chem. 1997, 62, 5242.

(22) Feherrari, A. F.; Kagumba, L.; Hadjikyriacou, S.; Chen, F.; Gaudiana, R. J. App. Poly. Sci. 2003, 87, 1634.

(23) Wolfe, J. P.; Singer, R. A.; Yang, B. H.; Buchwald, S. L. J. Am. Chem. Soc. 1999, $121,9550$.

(24) Vinutha, A. R.; Von Rudloff, E. Can. J. Chem. 1968, 46, 3743.

(25) Peyroax, E.; Berthiol, F.; Doucet, H.; Santeli, M. Eur. J. Org. Chem. 2004, 5, 1075.

(26) Guizzardi, B.; Mella, M.; Fagnoni, M.; Albini, A. Tetrahedron 2000, 56, 9383.

(27) Mori, Y.; Seki, M. J. Org. Chem. 2003, 68, 1571.

(28) Miller, J. A. Tetrahetron Lett. 2002, 43, 7111. 
(29) Brown, H. C.; Gupta, A. K.; Rangaishenvi, M. V.; Prased, J. V. N. V. Heterocycles 1989, 28, 283. 